\title{
From knowledge to added value A comparative, panel-data analysis of the innovation value chain in Irish and Swiss manufacturing firms
}

\section{Working Paper}

\section{Author(s):}

Roper, Stephen; Arvanitis, Spyros

Publication date:

2009-11

Permanent link:

https://doi.org/10.3929/ethz-a-005995727

Rights / license:

In Copyright - Non-Commercial Use Permitted

Originally published in:

KOF Working Papers 244 


\section{KOF Working Papers}

From Knowledge to Added Value: A Comparative, Panel-data Analysis of the Innovation Value Chain in Irish and Swiss Manufacturing Firms

Stephen Roper and Spyros Arvanitis 


\section{KOF}

ETH Zurich

KOF Swiss Economic Institute WEH D 4

Weinbergstrasse 35

8092 Zurich

Switzerland

Phone +41446324239

Fax +4144 6321218

www.kof.ethz.ch

kof@kof.ethz.ch 


\title{
From Knowledge to Added Value: A Comparative, Panel-data Analysis of the Innovation Value Chain in Irish and Swiss Manufacturing Firms
}

\author{
Stephen Roper* and Spyros Arvanitis** \\ * Centre for Small and Medium Enterprises, Warwick Business School, \\ University of Warwick, Coventry, CV4 7AL, UK \\ Email: Stephen.Roper@wbs.ac.uk \\ ** ETH Zurich, KOF Swiss Economic Institute, Weinbergstrasse 35, CH-8092 Zurich \\ Email: arvanitis@kof.ethz.ch
}

\begin{abstract}
The innovation value chain (IVC) divides the innovation process into three separate links or activities: knowledge gathering, knowledge transformation and knowledge exploitation. Here, we report a comparative panel data analysis of the IVC in Ireland and Switzerland. Both economies are small, very open and depend significantly on innovation to maintain competitive advantage. In recent years, however, R\&D and innovation growth in Ireland has been markedly stronger than that in Switzerland. We investigate these differences through the 'lens' of the IVC. We identify significant similarities between the determinants of firms' knowledge gathering behaviours in each country although firms are responding differently to financial and legal constraints. Strong complementarities emerge between external knowledge sources and between firms' internal and external knowledge. In terms of knowledge transformation - the development of new products or processes - we again find strong similarities between the two countries in terms of the determinants of the probability of innovation. The determinants of innovation intensity vary more, however, with external ownership significantly more important in Ireland. Finally, we consider the link between innovation and productivity which involves significant endogeneity issues. Two-stage estimation procedures do not suggest any significant links between innovation and productivity as we might expect from the macro-economic evidence.
\end{abstract}

Keywords: Innovation, value chain, Switzerland, Ireland

JEL Codes: O3, O5, P5 


\section{Introduction}

For small open economies such as Ireland and Switzerland, without significant natural resource endowments, innovation is an important element of sustained international competitiveness (Guellec and van Pottelsberghe 2004). This is perhaps most obvious in manufacturing products where Europe's high-cost producers compete in increasingly globalised markets. Innovation itself, however - the introduction of a new product or process - is only part of a wider process through which firms gather or create knowledge, translate that knowledge into specific market offerings, and then seek to exploit these products or process in the market ${ }^{1}$. Here, we are interested in modelling this innovation value chain (IVC) in Ireland and Switzerland, beginning with firms' attempts to assemble the bundle of different types of knowledge necessary for innovation (Hansen and Birkinshaw 2007; Roper, Love, and Du 2008). This may involve firms' in-house R\&D activities alongside, and either complementing or substituting for, external knowledge sources (Pittaway et al. 2004) ${ }^{2}$. Following firms' knowledge sourcing activity, the next link in the innovation value chain is the transformation of knowledge into physical innovations - new products or processes. This we model using the standard innovation production function approach (Geroski 1990; Love and Roper 1999) which relates innovation outputs (i.e. new products or processes) to knowledge inputs. In the spirit of models of open innovation, however, we allow firms' innovation outputs to reflect both internally-generated knowledge the result of in-house R\&D - and different types of knowledge sourced from external partners. The final link in the IVC relates to the exploitation of firms' innovations, i.e. the generation of added value. This we model using an innovation augmented production function (Geroski, Machin, and Van Reenen 1993).

Our empirical comparison relates to Ireland and Switzerland which despite common international trading environments have demonstrated very different economic growth rates and innovation performance over recent years ${ }^{3}$. The Republic of Ireland - the so called 'Celtic Tiger' - achieved economic growth rates averaging around 9.7 per cent

\footnotetext{
${ }^{1}$ Other firms may then benefit of course as knowledge or productivity spill-overs may also then lead to improvements in the performance of other co-related or co-located firms (Klette, Moen, and Griliches 2000; Beugelsdijck and Cornet 2001).

${ }^{2}$ Cassiman and Veugelers (2002), for example, find evidence of a complementary relationship between firms' internal R\&D and firms' ability to benefit from external knowledge sources. Other studies, however, have identified a substitute relationship between internal knowledge investments and external knowledge sourcing. Schmidt (2005, p. 14), for example, notes that for Germany 'firms with higher R\&D intensities have a lower demand for external knowledge than firms with lower R\&D intensities. The more $\mathrm{R} \& \mathrm{D}$ is done in-house the more knowledge is generated internally, and the less external knowledge is required'.

${ }^{3}$ Here we use the term Republic of Ireland to refer to the Irish nation state and Ireland to refer to the whole island of Ireland including both the Republic of Ireland and the UK region of Northern Ireland.
} 
between 1995 and 2004 (Northern Ireland 3.0 per cent) compared to an average of 1.4 per cent GDP growth in Switzerland ${ }^{4}$. Similarly, export growth averaged 9.9 per cent pa in the Republic of Ireland over the same period compared to an average of 1.9 per cent in Switzerland between 1995 and 2004. Conversely, over the period covered by our study (1994 to 2005) business R\&D spending in Switzerland increased steadily reaching 2.1 per cent of GDP in 2004, with public R\&D spending accounting for about 0.8 per cent of GDP. In the Republic of Ireland, R\&D spending accounted for 1.25 per cent of GDP in 2004 (1.48 per cent of GNP) with public R\&D spending accounting for around 0.55 per cent of GDP (see Table 1$)^{5}$.

A priori these contrasts in economic and $R \& D$ performance suggest that we might anticipate stronger innovation impacts on economic performance in Ireland than in Switzerland. Or, in terms of the IVC model, that we would anticipate stronger linkages between knowledge gathering, transformation and exploitation in Ireland. We begin in Section 2 by outlining our view of the innovation value chain and relate this to other theories of the firm. Section 3 describes our application of the innovation value chain model to data for manufacturing firms in Switzerland and Ireland. Section 4 reports the main empirical findings and Section 5 concludes with a brief review of the key empirical results and the policy and strategy implications.

\section{Conceptual Foundations}

Our focus here is the process through which firms' source, transform and exploit new - and potentially pre-existing - knowledge through innovation in the Swiss and Irish economies. At a fundamental level, this process can be seen as part of a broader evolutionary (Lamarkian) dynamic in which product and process technologies are steadily refined - and occasionally transformed - and in which firms upgrade their innovation capabilities through organisational learning (Nelson and Winter 1982). We interpret the innovation process as potentially 'open', however, emphasising the importance of the national innovation system within which firms are operating, and the potential benefits of operating in an environment where there exist rich external knowledge sources and extensive networking opportunities (Edquist 2004; Nelson 1993; Edquist and Hommen 2008).

\footnotetext{
${ }^{4}$ For the Swiss data see KOF-Analysen (2007).

${ }^{5}$ Irish GDP and exports data from www.cso.ie. R\&D data from Research and Development Statistics in Ireland, 2006, Forfas, Dublin. GDP figures for Northern Ireland from UK National Statistics.
} 
Within this perspective, the first link in the innovation value chain is firms' knowledge sourcing activity, and here we focus, in particular, on the factors which shape firms' engagement with alternative knowledge sources. More specifically, we identify five different types of knowledge sourcing activity which might shape firms' innovation: in-house R\&D (Shelanski and Klein 1995); forward linkages to customers (Joshi and Sharma 2004; Love and Mansury 2007); backward links to either suppliers or external consultants (Horn 2005; Smith and Tranfield 2005); horizontal linkages to either competitors or through joint ventures (Hemphill 2003; Link, Paton, and Siegel 2005); and, linkages to universities or other public research centres (Del Barrio-Castro and Garcia-Quevedo 2005). We then allow for potential complementarities or substitute relationships between knowledge derived from different sources (Veugelers and Cassiman 1999; Love and Roper 2004). Complementarities may arise, for example, between knowledge sources due to firms' improved scanning ability for external knowledge, the ability to substitute effectively internally generated for externally sourced knowledge or vice-versa, or enhanced absorptive capacity (Cohen and Levithal, 1989). Other studies, however, have identified a substitute relationship between internal knowledge investments and external knowledge sourcing. Schmidt (2005, p. 14) for example, notes that for Germany 'firms with higher R\&D intensities have a lower demand for external knowledge than firms with lower R\&D intensities. The more $R \& D$ is done in-house the more knowledge is generated internally, and the less external knowledge is required' (see also Love and Roper, 2001). In what follows we begin from this latter position, anticipating that firms with larger in-house knowledge resources are less likely to need to engage in external knowledge sourcing (Schmidt 2005). We summarise the probability that firms will engage in each of the five knowledge sourcing activities as follows:

$K S_{j i t}=\Sigma_{k} \beta_{k} K S_{k i t}+\gamma_{0} R_{j i t}+\gamma_{1} G O V T_{j i t}+\varepsilon_{i j t}$

(i: $1, \ldots \mathrm{N}$; firm; $\mathrm{j}, \mathrm{k}: 1, \ldots .5$; sourcing activity; $\mathrm{j} \neq \mathrm{k} ; \mathrm{t}=1, \ldots \mathrm{T}$ )

Where $\mathrm{KS}_{\mathrm{jit}}$ stands for the $\mathrm{i}^{\text {th }}$ firm's knowledge sourcing activity $\mathrm{j}$ (or $\mathrm{k}$ ) at time $\mathrm{t}$. The error term $\varepsilon_{j i t}$ is assumed to follow a multivariate normal distribution with mean zero and variance-covariance matrix $V$, where $V$ has values of 1 on the leading diagonal and $\rho_{\mathrm{jk}}=\rho_{\mathrm{kj}}$ for $\mathrm{j} \neq \mathrm{k}$. For any $\mathrm{j}, K S_{k i t}$ represents each firm's other knowledge sourcing activities. If $\beta$ is positive this would suggest a complementary relationship between firms' knowledge sourcing activities; negative $\beta$ would suggest a substitute relationship. $R I_{j i t}$ is a set of indicators of firms' knowledge resources and, as indicated earlier, we expect $\gamma_{0}$ to be negative. GOVT $T_{j i t}$ reflect access to government support for 
innovation and upgrading and in the light of general evidence on the additionality of government innovation support anticipate that $\gamma_{1}$ will be positive (Buiseret, Cameron, and Georgiou 1995; Falk 2004; Luukkonen 2000; OECD 2006).

The second link in the innovation value chain is the process of knowledge transformation, in which knowledge sourced by the enterprise is translated into innovation outputs. This is modelled using an innovation or knowledge production function in which the effectiveness of firms' knowledge transformation activities is influenced by firms' own knowledge resources (Griliches 1992; Love and Roper 1999). In terms of innovation outputs, we follow the suggestion of Pittaway et al. (2004) who emphasise the importance of examining both product and process innovation, and we anticipate that knowledge from different sources may have differential product and process effects. Joshi and Sharma (2004), for example, suggest the importance of knowledge of customers' preferences in shaping firms' innovation success, while Roper et al. (2008) emphasise the greater value of backwards and public knowledge linkages for process change. This suggests the possibility of different routes through which knowledge of different types might influence different aspects of firms' innovation activity and hence business performance. In general terms we write the innovation production function as:

$I N N O_{i t}=\Sigma_{k} \varphi_{0 k} K S_{k i t}+\varphi_{1} R^{\prime}{ }_{i t}+\varphi_{2} G O V T_{i t}+u_{i t}$

Where $\mathrm{INNO}_{\text {it }}$ is an innovation output indicator, $\mathrm{k}=1, \ldots, 5$, indicate the alternative knowledge sources identified earlier, $\mathrm{u}_{\mathrm{it}}$ is the error term and other variable definitions are as above. In the innovation production function, we have different sign expectations for some of the independent variables from that in the knowledge sourcing equations. In particular, where firms' internal knowledge resources are strong we would expect this to contribute positively to the efficiency with which firms develop new innovations but to discourage knowledge sourcing (Crepon et al. 1998; Loof and Heshmati 2001, 2002). However, as in the knowledge sourcing models, we expect firms' innovation outputs to be positively related to government assistance (Link, Paton, and Siegel 2005).

The final link in the innovation value chain is knowledge exploitation, i.e. the process by which enterprise performance is influenced by innovation (Geroski, Machin, and Van Reenen 1993). At this point we envisage that firms' acquired knowledge has been 
codified into specific product or process innovations. It is therefore these variables, which represent the firms' new market offerings, that might drive enhanced business performance, and which provide the link between firms' knowledge sourcing activities and performance. The strength of this linkage, however, will depend on firms' ability to effectively implement their new products or processes and then appropriate the full market rent from their innovations. To model this effect we use an augmented production function including the innovation output measures on the right hand side. Firm characteristics - including capital intensity - are used to capture firms' ability to appropriate post-innovation returns. The augmented production function is expressed as:

$B P E R F_{i t}=\lambda_{0} I N N O_{i t}+\lambda_{1} X_{i t}+v_{i t}$

Where $\mathrm{BPERF}_{\text {it }}$ is an indicator of business performance - here labour productivity or value-added per employee, $\mathrm{INNO}_{i t}$ is a vector including innovation outputs measures for both process and product innovation, and $\mathrm{X}_{\mathrm{it}}$ is a set of enterprise specific variables that are hypothesized to affect productivity.

\section{Data and methods}

Our empirical analysis is based on data from two sources: the Irish Innovation Panel (IIP) which provides information on the innovation activities of Irish manufacturing firms (both in the Irish Republic and Northern Ireland) and the Swiss innovation panel (SIP) which provides information on the activities of Swiss manufacturing firms. The Irish Innovation Panel provides information on manufacturing plants' technology adoption, networking and performance over the period 1991-2005. More specifically, the IIP comprises five surveys or waves conducted using similar survey methodologies and questionnaires with common questions (Roper and Hewitt-Dundas 1998; Roper and Love 2005; Roper 1996). Each of the five surveys covers the innovation activities of manufacturing establishments with 10 or more employees over a three year period. For manufacturing each of the five surveys was undertaken by post using a sampling frame provided by the economic development agencies in Ireland and Northern Ireland ${ }^{6}$. The IIP is a highly unbalanced panel reflecting non-

\footnotetext{
${ }^{6}$ The initial survey, undertaken between October 1994 and February 1995, related to plants' innovation activity over the 1991-93 period, and achieved a response rate of 38.2 per cent (Roper et al., 1996; Roper and Hewitt-Dundas, 1998, Table A1.3). The second survey was conducted between November 1996 and March 1997, covered plants' innovation activity during the 1994-96 period, and had a response rate of 32.9 per cent (Roper and Hewitt-Dundas, 1998). The third survey covering the 1997-
} 
response but also the closure and opening of manufacturing units over the 15 year period covered by the panel. The panel itself contains 4525 observations from 2564 establishments and representing an overall response rate of 33.2 per cent (Northern Ireland, 39.1 per cent; Ireland 30.5 per cent). Here our analysis is based on the most recent four waves of the IIP covering the 1994 to 2005 period.

In the IIP firm's knowledge sourcing activities are represented by a series of binary variables denoting whether they had in-house R\&D and whether they link to different types of partners as part of their innovation activity over the previous three years ${ }^{7}$. Across the panel, the most common form of knowledge sourcing was in-house R\&D, being undertaken by 47.4 per cent of establishments (Table 2). In terms of firms' external knowledge sourcing activities the IIP like other innovation surveys suggests that linkages along the supply chain are most common as part of firms' innovation activity - backwards linkages (32.2 per cent) were most common followed by forwards linkages (25.7 per cent). Horizontal linkages (11.7 per cent) and links to public knowledge sources (17.3 per cent) were less common but still formed a potentially important part of the knowledge sourcing strategies of a significant proportion of enterprises.

Innovation in the IIP is represented by three main variables. First, the proportion of firms' total sales (at the end of each three year period) derived from products newly introduced during the previous three years. This variable - "innovation success" reflects not only firms' ability to introduce new products to the market but also their short-term commercial success. On average, 15.1 per cent of firms' sales were derived from new products across the IIP (Table 2). The second innovation output measure is a binary indicator of product innovation which reflects the extent of product innovation within the target population. The third innovation output measure is a similar binary indicator of process innovation, an indication of the extent of process innovation within the target population ${ }^{8}$. Over the whole sample, 63.9 per cent of firms were product innovators while 58.2 per cent were process innovators (Table 2). Notably, however, the overlap between the group of product and process innovators

\footnotetext{
99, period was undertaken between October 1999 and January 2000 and achieved an overall response rate of 32.8 per cent (Roper and Anderson, 2000). The fourth survey was undertaken between November 2002 and May 2003 and achieved an overall response rate of 34.1 per cent. The IIP5, conducted between January and June 2006, had an overall response rate of 28.7 per cent.

${ }^{7}$ Variable definitions are included in Table A1. Tables A2 and A3 report variable covariances.

${ }^{8}$ For this variable a product (process) innovator was defined as an establishment which had introduced any new or improved product (process) during the previous three years.
} 
was not complete: around 70.2 per cent of product innovators were also process innovators, with 75.3 per cent of process innovators also being product innovators.

Swiss innovation data provides information on manufacturing firms' innovation performance, innovation input, R\&D cooperation, external knowledge sources, IPR, innovation obstacles, technological potential, and public innovation promotion over the period 1990 - 2005 (triennial). However the questionnaires in 1990 and 1993 were much less comprehensive than the later ones. The surveys are conducted based on a stratified random sample from the Swiss business census on firms with more than 5 employees (firm panel) covering the manufacturing, construction, and service sectors. For the international comparison at hand we refer to firms with 10 or more employees. Only data from the manufacturing sector and only data from the surveys 1996, 1999, 2002, and 2005 are used in this investigation. The SIP contains around 3000 manufacturing firms and the response rates are 33.5 per cent, 33.8 per cent, 44.6 per cent, and 41.6 per cent for the years 1996, 1999, 2002, and 2005 respectively. Like the IIP, the Swiss innovation panel is a highly unbalanced panel, reflecting non-response ${ }^{9}$.

Looking at the three innovation output measures, we find that in the SIP the proportion of new (innovative) products on total sales averages around 13 per cent slightly under the 15 per cent in Irish firms (see Table 3$)^{10}$. The second innovation indicator we use is the proportion of firms undertaking product innovations. In Switzerland, this share decreased from 72 per cent in 1996 to 55 per cent in 2005, an average of around 68 per cent compared to 63 per cent in Ireland (Table 3). The third innovation indicator is the proportion of firms undertaking process innovation. Here, the Swiss share also decreased over the years from 71 per cent in 1996 to 45 per cent 2005, averaging 58 per cent (Ireland, 59.2 per cent).

In addition to firms' knowledge sourcing and innovation activities the IIP and SIP provide a range of indicators of the strength of firms' internal knowledge resources. This include variables which might give a quantitative indication of the scale of firms' knowledge resources - e.g. plant size, finance constraints - as well as other factors which might suggest the quality of firms' in-house knowledge base - e.g. multinationality, plant vintage, human resource quality and production type. Multi-

\footnotetext{
${ }^{9}$ For a detailed discussion of methodology, questionnaires, and descriptive results for the SIP see Arvanitis et al. (1998, 2001, 2004, and 2007).

${ }^{10}$ The figures for the respective years include also non-response weights, while the overall average is only firm-weighted.
} 
nationality is included here to reflect the potential for intra-firm knowledge transfer between national markets and plants, while plant vintage is intended to reflect the potential for cumulative accumulation of knowledge capital by older establishments (Klette and Johansen 1998), or plant life-cycle effects (Atkeson and Kehoe 2005). Since Griliches (1995), literature on publicly funded R\&D has suggested repeatedly, that government support for R\&D and innovation can have positive benefits for firms' innovation activity both by boosting levels of investment and through its positive effect on organisational capabilities (Buiseret, Cameron, and Georgiou 1995) ${ }^{11}$. Arguably, this is particularly important in Ireland and Northern Ireland, which during much of the period covered by the IIP enjoyed EU Objective 1 status which provided resources for substantial investments in developing innovation and R\&D capability (Meehan 2000; O'Malley, Roper, and Hewitt-Dundas 2008). Indeed, over the sample period we find nearly a third of Irish firms receiving support for innovation or investment, around four times as large a proportion as that in Switzerland (Table 2). Finally, to reflect potential differences in the operating environment between the Republic of Ireland and Northern Ireland we include a locational dummy which takes value 1 if a plant is located in Northern Ireland.

Two sets of econometric issues arise in the estimation of the innovation value chain model. These relate first to potential simultaneity between elements of the value chain and secondly to the choice of appropriate estimators for each value chain element. In the context of the survey data considered here, however, with a number of missing values and unbalanced panels estimation decisions also need to take into account potential efficiency losses where we allow for simultaneity. To estimate the simultaneous knowledge sourcing equations (1) where the dependent variables are binary indicators of firms' use of individual knowledge sources, for example, the most efficient approach would be multivariate probit. As Greene (2000) p. 616 notes, however, the efficiency gains from MVP are likely to be reduced where the anticipated determinants of each knowledge sourcing activity are similar and there is potential simultaneity between the knowledge sourcing activities. Other difficulties arise in the application of an MVP approach to our survey data. First, adopting a simultaneous estimation approach exacerbates the loss of observations due to missing data in our sample, offsetting any gains in statistical efficiency. Second, in practice, achieving convergence with an MVP estimator places some limits on the degree of

11 Trajtenberg (2001), for example' offers more direct evidence on the links between public R\&D support and firms' proprietary knowledge base. In his examination of government support for commercial R\&D in Israel operated by the Office of the Chief Scientist (OCS), he concludes that 'industrial R\&D expenditures are closely linked (with a reasonable lag) to patents, and so are $R \& D$ grants awarded by the OCS'. 
simultaneity which it is possible to include (Roper 2006 ). In our IVC estimates this is particularly undesirable because in the first stage of the IVC we are interested in the complementary or substitute relationship between knowledge sourcing activities. Instead of using MVP we therefore prefer to adopt a simpler approach using five simple probit models, one for each knowledge sourcing activity. This approach, while sacrificing some statistical efficiency, provides substantial gains in terms of the number of observations used, and our ability to reflect more fully the relationship between knowledge sourcing activities.

The appropriate estimation method for the innovation production function depends primarily on the nature of the dependent variable. Binary indicators for product or process innovation again suggest simple probit models, while the percentage of sales derived from new products has both upper and lower bounds and suggests Tobit. A potential issue at this stage of the innovation value chain, however, is selectivity bias (e.g. Lööf and Heshmati, 2002). In the innovation production function this may arise from two main sources. First, the group of innovating firms may be self-selecting in some sense inducing a bias between the expected values of the parameters of the estimated innovation production function and the data generating mechanism for the population as a whole. Or, due to sample design, non-response, or survey methodology, the selected sample may be atypical in some way of the underlying population. Elsewhere (i.e. Love et al., 2006), we have explored the potential importance of such selection bias in the innovation decision using the IIP with largely reassuring results, suggesting little evidence of any significant selection bias in the innovation decision, perhaps due to the broadly-based and nationally representative sampling approach used in our survey data and the particular questioning approach adopted $^{12}$. For the Swiss data a short survey of a random sample of the nonrespondents showed that there is no discernible selection bias. In the estimation of equation (2) reported here we therefore base our analysis on standard econometric approaches, although for comparison we also report additional estimates of equation (2) for innovation success based on the sample of product innovators only (i.e. excluding the lower limit value) ${ }^{13}$.

\footnotetext{
${ }^{12}$ For example, non-response surveys conducted after each main survey suggested little evidence of any systematic difference in innovation behaviours between respondents and non-respondents (e.g. Roper and Hewitt-Dundas, 1998, Annex 1). Question non-response was also relatively limited. For example, 91 per cent of respondents indicating they were product innovators (binary response) also provided information on the extent of their innovation activity.

${ }_{13}$ Another potential issue is multi-collinearity between the knowledge sourcing variables themselves and other elements of the innovation production function (compare equations (1) and (2), for example). In practice, however, we find something of an empirical separation between the two models with
} 
Two main econometric issues arise in operationalising the augmented production function (equation 3) - heterogeneity in performance outcomes and potential endogeneity of the innovation output measures. In terms of heterogeneity, it is clear that very large variations can exist in business performance even in narrowly defined industries $^{14}$. In practice this proves to be more of an issue in the IIP than our Swiss data, and to counter any bias introduced by potential outliers we therefore exclude a small proportion of extreme values in the Irish productivity equations. The potential endogeneity of innovation output measures in models of business performance has been discussed extensively in the literature, and a range of potential approaches have been adopted including two-stage estimation methods (e.g. Crépon et al, 1998) and the simultaneous estimation of the innovation and augmented production functions (e.g. Lööf and Heshmati, 2002). Here, we report two alternative estimations of the augmented production functions first including the innovation output terms directly on the RHS, and secondly a two-stage procedure in which these are replaced by the fitted values from the relevant innovation production functions (i.e. equation 2). Happily the results from the two different estimation approaches are broadly similar.

\section{Empirical Results}

The initial link in the innovation value chain is firms' knowledge sourcing activity. Panel data probit models (with random effects) for each of the knowledge sourcing activities are reported in Table 3 for Switzerland and Ireland. Two issues are of particular interest here: first, what pattern of complementarity or substitutability exists between firms' knowledge sourcing activity; and, secondly, what other factors determine firms' knowledge sourcing behaviour. Our results suggest marked similarities between both patterns of complementarity between knowledge sourcing activities in Switzerland and Ireland and also in the influence on knowledge sourcing of the majority of other factors included in the models (Table 3).

In terms of the relationship between knowledge sourcing activities, these are almost universally complementary in both countries (Table 3). For Switzerland we see strong and significant and positive associations between in-plant $R \& D$ and forward knowledge sourcing and between in-plant R\&D and public knowledge sourcing (also in accordance to Woerter 2008). In Ireland, we see similar significant positive

different factors determining firms' knowledge sourcing and knowledge transformation (compare Tables 3 and 4). In practice this should minimise any multi-collinearity issues.

${ }^{14}$ See Caves(1998) for a survey and on innovation behaviour see Lööf and Heshmati (2002). 
associations but also find a significant positive association between in-plant R\&D and backwards knowledge sourcing. This complementarity between internal knowledge generation (i.e. in-plant R\&D) and external knowledge sourcing is consistent with the results of Cassiman and Veugelers (2002) but runs contrary to the results of Schmidt (2005) and Love and Roper (2001) which both suggest a substitution relationship between internal R\&D activity and external knowledge sourcing (see also Irwin 1996). We also find strong evidence of complementarity between different external knowledge sourcing activities for both Switzerland and Ireland with forwards and backward knowledge sourcing and backward and public knowledge sourcing being particularly strongly linked (Table 3). One possible explanation is that enterprises are obtaining economies of scope as they learn to manage external relationships effectively and so benefit more from extending the range of their external knowledge sourcing activities.

In terms of the other determinants of knowledge sourcing our results suggest contrary to expectations - that the probability of external knowledge sourcing is positively related to firms' internal knowledge resources (Schmidt, 2005). For example, for Ireland we find for in-house R\&D as well as for public sourcing, for Switzerland only for in-house $R \& D$ a non-linear (inverted ' $U$ ') shape relationship between each knowledge sourcing activity and plant size which we interpret as an indicator of the likely scale of firms' internal knowledge resources (Table 3). Skill levels - measured by the proportion of the workforce with a degree level qualification - are also positively related to knowledge sourcing in both countries, suggesting a link between the quality of firms' in-house knowledge resources and external knowledge sourcing (Table 3). The strongest skill effects are evident in terms of in-plant R\&D and public knowledge sourcing which includes that from universities. The latter effect, in particular, may reflect the personal networks of firms' graduate employees (Santoro and Bierly 2006; Perkmann and Walsh 2007). As we anticipate that public support for $\mathrm{R} \& \mathrm{D}$ and innovation is also resource augmenting in some sense it is not surprising that this too has positive effects on knowledge sourcing in both countries, increasing the probability of in-house $R \& D$ and also collaboration with public knowledge sources.

More significant differences were observed between the impact of financial and legal constraints on knowledge sourcing behaviours in the two countries. In Switzerland, financial constraints were having no effect on firms' in-plant R\&D (also in accordance to the findings in Arvanitis 2008) but were increasing the probability that 
firms were engaging in forwards or horizontal knowledge sourcing. One potential interpretation is that Swiss firms were reacting to this financial pressure by trying to reduce the financial risk of innovation, either by risk sharing through innovation partnerships (horizontal links), or by ensuring that their innovations met customer needs (forward links) (Irwin 1996). In Ireland, firms' response to financial constraints on innovation seems less complex with financial constraints associated instead with less likelihood that firms were undertaking in-plant R\&D. Legislative or regulatory constraints also had different influences on knowledge sourcing in the two countries. In Switzerland, legislative constraints were associated with a lower probability of inhouse R\&D but increased probabilities of all other knowledge sourcing activities (Table 3). In Ireland, legislative barriers were generally having a weaker effect on external knowledge sourcing but were associated with an increased probability that a firm would be undertaking in-house $R \& D$. This contrast suggests that firms in the two countries were adopting different strategies for coping with regulatory restrictions on their innovation activity, although both involved additional knowledge sourcing. In Ireland, firms were adopting a more self-sufficient approach with an increased probability of in-plant R\&D; in Switzerland more collaborative responses are evident with increases in external knowledge sourcing.

Whether or not a plant was externally owned was also having a different effect on knowledge sourcing in two countries. In Switzerland, externally-owned firms had essentially similar profiles of knowledge sourcing activity to Swiss-owned firms although they were more likely to be engaged in horizontal innovation partnerships. In Ireland, differences between knowledge sourcing by externally-owned and locallyowned firms are more extensive with externally-owned firms: less likely to be engaging in in-house $R \& D$, but more likely to be engaging in backwards or public knowledge sourcing. This reflects earlier discussion of the differences between externally-owned and indigenously-owned firms in Ireland with the former generally thought to have higher levels of technological capability (Wrynn 1997; HewittDundas et al. 2002). Differences in the impact of external ownership on patterns of knowledge sourcing in the two countries may also reflect differences in the nature of inward investment: partner seeking in Switzerland and resource or market seeking in Ireland (Driffield 2005).

In summary, we find that knowledge sourcing in both Ireland and Switzerland is marked by strong complementarities, perhaps suggesting economies of scope in the management of firms' external relationships. We also find strong similarities in the 
effect of indicators of firms' knowledge resources on knowledge sourcing: in both economies firms with stronger internal knowledge resources seem more likely also be engaging in external knowledge sourcing. We therefore find little evidence for the type of substitution of external for internal knowledge suggested by the resource based view. Rather our results are suggestive of a Schumpeter Mark 2 model with firms with strong pre-existing knowledge resources most active in seeking to reinforce those advantages.

The second link in the innovation value chain is the transformation of knowledge into product and process innovation represented by the innovation production function (equation 2). Here, we are interested in the contribution of each knowledge source to innovation as well the effect of factors contributing to the efficiency of enterprises' knowledge transformation activity. Estimates of the innovation production functions for the three innovation output measures, and for the two countries, are reported in Table 4. The final column in Table 4 reports sub-sample estimates for enterprises with non-zero innovation success.

Knowledge sourcing of different types has, as expected, a generally positive and significant impact on innovation. In-plant $R \& D$, for example, has a strongly positive and significant effect on the probability of undertaking both product and process innovation in each country as well as on the proportion of sales from innovative firms. Interestingly, however, in Ireland in-plant $R \& D$ has a weak negative effect on innovation intensity where the model is estimated only for the sub-sample of innovative firms. The suggestion is that $\mathrm{R} \& \mathrm{D}$ is having somewhat different innovation effects in the two countries: in Ireland, in plant R\&D is boosting the likelihood of enterprises engaging in product innovation, but having little impact on the market success of that innovation activity; in Switzerland R\&D is having positive effects both on the probability that firms will engage in innovation but also in the market success of that innovation activity. This, perhaps, reflects the point made earlier about the greater tendency for Swiss firms to engage customers in their innovation attempts.

As expected, forward knowledge sourcing has significant positive influence on both the probability of undertaking product innovation as well as innovation success in both countries. In both countries forward knowledge sourcing also has only a marginally significant and positive effect on the probability of process innovation 
perhaps reflecting the stronger impact of customer-led innovation on product rather than process change (Karkkainen, Phiippo, and Tuominen 2001) (Table 4). Reflecting their differential importance in the population of Irish and Swiss firms (Table 2) backwards and horizontal knowledge sourcing have different innovation effects in the two countries. In Switzerland neither sort of linkage has any consistent innovation effect (with the exception of the positive effect of backward sourcing on process innovation; see Arvanitis 2008 for more detailed Swiss results), while in Ireland both horizontal and backwards linkages have significant product and process innovation effects (Table 4). As with in-house R\&D, however, these effects are only important for the probability of innovation and prove less important for the success of innovation in the sub-sample estimation (Table 4). Finally, unlike the other knowledge sources, we find no evidence in either country that links to public knowledge sources (i.e. universities, public and industry-owned laboratories) have any positive impact on either the probability of process or product innovation, or the proportion of sales derived from innovative products (Table 4). In Switzerland, the effects of public knowledge sourcing is insignificant, a result consistent with the idea that innovations developed in university collaborations may take longer to come to fruition than those developed with commercial partners. The negative and significant effects from public knowledge sourcing in Ireland, however, are more difficult to explain (Jordan and O’Leary 2007).

These direct effects from knowledge sourcing are not the whole story because, in addition to their direct effects on innovation, firms' knowledge sourcing activities may also be having an indirect effect through their complementarity with other knowledge sourcing activities (Table 3). In house R\&D, for example, is having a positive and significant direct effect on innovation (Table 4). However, it is also having a positive indirect effect on innovation through its complementary effect on the probability that firms will engage in forward knowledge sourcing (Table 3). This indirect effect is an 'absorptive capacity' effect of the sort envisaged by Cohen and Levinthal (1989, 1990) and Zahra and George (2002). Even where the direct effects of knowledge sourcing activities on innovation are negative, as in the case of public knowledge sourcing in Ireland, their overall effect may still be positive due to the balance between 'direct' and 'absorptive capacity' effects.

Aside from the knowledge sourcing variables we see marked similarities between the sign patterns and significance of other key variables across the Swiss and Irish innovation production function estimates. Both suggest the anticipated positive 
relationship between the strength of firms' internal knowledge resources and, ceteris paribus, their level of innovation. Establishment size, for example, generates a significant inverted ' $U$ ' function for both countries for the probability of product and process innovation although, reflecting the findings of other studies, there is little clear relationship between plant size and the proportion of sales derived from innovative products. This suggests that the scale of firms' internal knowledge resources is positively linked to the probability of innovation at least. Also, in both countries we see a clear positive relationship between skill levels and both the probability and market success of product innovation. Less intuitive perhaps is the common result that graduate skill levels are negatively, and significantly, related to process change in both countries. ${ }^{15}$

As in terms of knowledge sourcing, we see no difference between the innovation activities of externally-owned and locally-owned firms in Switzerland (Table 4). In Ireland, however, we again see more marked differentials in the full-sample estimates: externally-owned firms in Ireland are significantly more likely to be undertaking product and process innovation, and also to have a higher proportion of sales derived from innovative products (Table 4). Focussing on innovative plants alone, however, suggests no significant difference between the innovation success of innovating Irish plants and innovating externally-owned plants. Plant vintage effects are also similar between the two areas with older firms equally likely to be undertaking product and process innovation but having significantly lower proportions of sales derived from innovative products in both countries. This is consistent with a life-cycle model of plant development which envisages declining levels of innovation and increasing product maturity as plants age (Atkeson and Kehoe 2005).

Financial and regulatory constraints also have very similar effects on innovation outcomes in the two countries. In Switzerland, shortage of finance has a negative effect on the probability of product innovation only, while in Ireland its primary negative effect is on the probability of process change. Legislative effects are more mixed, having negative but insignificant effects on the probability of product innovation in both countries but having significant positive effects on both Swiss and Irish firms' innovation success (Table 4). The implication is that legislation or

\footnotetext{
${ }^{15}$ At least for Switzerland some evidence was found that multi-collinearity between the variable for inhouse R\&D and the variable for graduate skill levels could be responsible for this negative effect. An estimate of the process innovation equation without the variable for in-house $R \& D$ showed a positive but statistically insignificant effect for graduate skill levels.
} 
regulatory barriers may reduce the probability that firms becoming innovators but may create new opportunities for those firms which are already innovative.

Government support for R\&D and innovation also proves important in both countries increasing the probability of undertaking innovation in both areas and also the proportion of sales from innovative products in Ireland. This may reflect the efficacy of Irish innovation policy but may also capture the significantly larger proportion of Irish firms which received support for innovation during the study period. Some care is necessary in interpreting the policy implications of this result (Greene, 1997, p. 982). In particular, the coefficients on the policy support - treatment terms - reflect the combination of 'assistance' and 'selection' effects ${ }^{16}$.

To summarize, our innovation production functions worked out largely as anticipated, and with a rather surprising degree of similarity between the two countries in terms of the positive role of knowledge sourcing and firms' internal knowledge resources in shaping innovation. Two interesting divergences occur, however. First, the profile of external knowledge sourcing effects on innovation is different in each country with the strongest impacts coming from forward knowledge sourcing in Switzerland but backwards knowledge sourcing being more important in Ireland. Also, only in Ireland do we find a negative public knowledge sourcing effect. Second, in Switzerland we see little divergence in the innovation behaviours of locally and externally-owned firms. This differs markedly from Ireland where externally-owned firms are more likely to be both product and process innovators.

The final element of the innovation value chain relates (log) value added per employee to product innovation, innovation success and process innovation. Two different forms of the augmented production are considered here. The first relates log value added directly to the innovation output indicators (Table 5) and, in order to reduce any impact from the endogeneity of the innovation indicators, Table 6 relates $\log$ value added to the fitted values of the innovation production functions reported in Table 4.

\footnotetext{
${ }^{16}$ Separately identifying the selection and assistance effects requires a different estimation approach to that adopted here. See Maddala (1983) pp. 257-290 for a general discussion of the issue and Roper and Hewitt-Dundas (2001)for an application.
} 
In the Swiss production functions the indicators for product (process) innovation and innovation success are positive (negative) but insignificant when included either in their natural forms (Table 5) or as fitted values (Table 6). The Irish results are uniformly less satisfactory than those for Switzerland with the innovation indicators taking uniformly negative signs in the production functions and largely being insignificant. The only significant coefficient however is that on the percentage of innovative products in the directly estimated models (Table 5). Including the predicted values of the innovation indicators for Ireland has little effect (Table 6) with innovation coefficients remaining negative and insignificant.

In terms of our initial assertion these results provide little evidence for our hypothesis that innovation should be of greater importance for productivity in Ireland rather than Switzerland. Instead, other aspects of the production capability of firms prove much more important with plants which have higher capital intensity and skill endowments being significantly more productive. In both countries productivity also has an inverted ' $U$ ' shaped relationship to plant size and is higher in older plants. Notably too, externally-owned firms in both countries are significantly more productive than indigenously owned firms.

\section{Conclusions}

Over the last decade the economies of Ireland and Switzerland have grown at radically different rates as innovation has declined in Switzerland and remained broadly stable in Ireland. This raises the question of the contribution of innovation to explaining productivity in each country. Here we use the notion of the innovation value chain to explore the determinants of innovation in the two countries and its subsequent contribution to innovation at the firm level. The evidence suggests marked similarities between the determinants of innovation in the two countries but is perhaps less convincing in explaining productivity differences in the two economies. In particular, we find strong evidence for the importance of supply-side and capability influences in determining innovation outputs alongside firms' use of external knowledge sources. Firms' responses to regulatory and financial pressures do differ, however.

In the first link in the IVC we find strong complementarities in between firms' knowledge sourcing activities in both countries, perhaps suggesting economies of scope in the management of firms' external relationships. We also find strong 
complementarities between firms' internal knowledge resources and their engagement with external knowledge sources for innovation. This tends to contradict the type of substitution of external for internal knowledge which would be suggested by the resource-based view. Instead, our results are suggestive of a Schumpeter Mark 2 model with firms with strong pre-existing knowledge resources most active in seeking to reinforce those advantages.

The second link in the IVC relates to the translation of knowledge into codified innovations in product and process. Here, we find considerable similarity between the two countries in terms of the positive role of knowledge sourcing and the importance of firms' internal knowledge resources in shaping innovation. In terms of the types of external linkages which contribute to innovation, however, we see some differences between Irish and Swiss firms. In Switzerland, forward linkages prove important, while backwards linkages prove more important in Ireland. Also, only in Ireland do we find a significantly negative public knowledge sourcing effect. Ownership effects also work differently in the two countries in terms of innovation outputs suggesting stronger distinctions between locally and externally-owned firms in Ireland than in Switzerland in terms of firms' knowledge transformation capability.

The final element of the IVC relates to the impact of innovation on productivity. Here we find no evidence of significant innovation-productivity linkages for both countries. Instead, productivity seems to be much more strongly influenced by other aspects of firms' production capability such as capital intensity and skill endowments. Other aspects of Irish firm performance - most notably employment and sales growth have, however, been shown elsewhere to be positively related to innovation outputs (Roper, Love, and Du 2008).

Our analysis emphasises a number of empirical regularities in firms' knowledge sourcing and innovation activities; the complementarity between internal and external knowledge resources; the positive contribution of external knowledge to innovation; the inverted ' $U$ ' shape relationship between innovation and firm size; and, the positive effects on innovation of plant vintage, skill levels and government assistance. Other environmental factors such as legislation and regulatory factors seem to generate different innovation responses in the two countries, and provide an interesting focus for future research. Ownership effects also differ, with more marked discrepancies 
evident between the knowledge transformation capabilities of externally and locallyowned firms in Ireland than in Switzerland. 
Table 1: Comparative Data

\begin{tabular}{|c|c|c|c|c|}
\hline & $\begin{array}{r}\text { Republic } \\
\text { of Ireland }\end{array}$ & $\begin{array}{r}\text { Northern } \\
\text { Ireland } \\
\end{array}$ & Ireland & Switzerland \\
\hline \multicolumn{5}{|l|}{ A. Land Area and Population } \\
\hline Land area $\left(\mathrm{km}^{2} \mathrm{x} 1000\right)$ & 81519 & 13602 & 95121 & 41285 \\
\hline Population (x million, 2006) & 4.239 & 1.741 & 5.98 & 7.5 \\
\hline Population density (per km², 2006) & 52 & 128 & 62 & 182 \\
\hline \multicolumn{5}{|l|}{ B. Labour Market } \\
\hline Working age employment rate ( per cent, 2006) & 57.6 & 69.4 & 60.4 & 81.2 \\
\hline Unemployment rate ( per cent, 2006) & 4.4 & 3.2 & 4.1 & 3.3 \\
\hline \multicolumn{5}{|l|}{ C. Openness } \\
\hline Total exports ( per cent of GDP) & 81.6 & & & 52.5 \\
\hline Total imports ( per cent of GDP) & 69.3 & & & 44.9 \\
\hline \multicolumn{5}{|l|}{ C. Composition of GDP (2006) } \\
\hline Primary (agriculture, fishing, mining) & 2.5 & 3.2 & 2.6 & 1.1 \\
\hline Manufacturing (incl. construction for $\mathrm{CH}$ ) & 25.4 & 16.1 & 23.7 & 25.9 \\
\hline Construction & 9.4 & 7.7 & 9.1 & \\
\hline Services (for $\mathrm{CH}$ ) & & & & 67.0 \\
\hline Distribution, transport and communications & 15.0 & 23.0 & 16.5 & \\
\hline public admin and defence & 3.5 & 11.1 & 4.9 & \\
\hline other services & 44.1 & 38.9 & 43.2 & \\
\hline \multicolumn{5}{|l|}{$\begin{array}{l}\text { D. R\&D Spending } \\
\text { (\% GNP, Ireland 2006, \% GDP, Switzerland 2004)) }\end{array}$} \\
\hline R\&D Spending & 1.6 & 1.3 & 1.5 & 2.9 \\
\hline - Industry & 1.1 & 0.6 & 1.0 & 2.1 \\
\hline - Higher education & 0.4 & 0.6 & 0.4 & 0.7 \\
\hline - Other & 0.1 & 0.1 & 0.1 & 0.1 \\
\hline
\end{tabular}

Notes: Land area and population: population estimates relate to 2006, Sources: Northern Ireland Annual Abstract of Statistics (NIAAS), NISRA, Belfast and CSO. Labour Market: Employment rate as per cent of working age population (in Switzerland between 15 and 64 years), unemployment rate ILO unified rate, Sources: Annual Abstract of Statistics, CSO Dublin and NIAAS, Statistic Switzerland. Openness: No figures are available for Northern Ireland; for Ireland Source: CSO, Dublin. Total Exports and Imports as a proportion of current prices GDP 2006. Composition of GDP 2006: Source: Annual Abstract of Statistics, CSO Dublin. R\&D Spending: For Ireland, R\&D Spending: Ireland as per cent of GNP, 2006; Source: Research and Development Statistics in Ireland, 2006, Forfás, Dublin. For Northern Ireland, Northern Ireland R\&D Statistics 2006, Department of Trade, Enterprise and Investment, Belfast. Estimated as a proportion of 2004 GDP allowing for growth at 3.0 per cent pa during 2005 and 2006. For Switzerland all information are from Swiss Statistics (www.bfs.admin.ch). 
Table 2: Survey Descriptives

\begin{tabular}{|l|rrr|rrr|}
\hline & \multicolumn{3}{|c|}{ Switzerland } & \multicolumn{3}{c|}{ Ireland } \\
\cline { 2 - 7 } & $\mathrm{N}$ & Mean & \multicolumn{1}{c|}{ Std. } & $\mathrm{n}$ & \multicolumn{1}{c|}{ Mean } & \multicolumn{1}{c|}{ Std. } \\
\hline & & & & & & \\
Knowledge Sourcing & & & & & & \\
In plant R\&D & 4171 & 0.629 & 0.483 & 3530 & 0.474 & 0.499 \\
Forwards & 4177 & 0.517 & 0.500 & 3530 & 0.257 & 0.437 \\
Backwards & 4176 & 0.038 & 0.191 & 3530 & 0.322 & 0.467 \\
Horizontal & 4175 & 0.306 & 0.461 & 3530 & 0.117 & 0.322 \\
Public & 4177 & 0.100 & 0.299 & 3530 & 0.173 & 0.378 \\
Innovation & & & & & & \\
Product innovation (0/1) & 4177 & 0.682 & 0.466 & 3453 & 0.639 & 0.480 \\
Process innovation (0/1) & 4177 & 0.586 & 0.493 & 3445 & 0.582 & 0.493 \\
Innovative products (\% sales) & 4177 & 13.313 & 18.287 & 3230 & 15.134 & 22.511 \\
Productivity & & & & & & \\
Log Value Added per & & & & & & \\
employee & 4133 & 11.819 & 0.409 & 2488 & 3.435 & 1.162 \\
Other factors & & & & & & \\
Plant vintage & 4072 & 64.725 & 43.014 & 3453 & 28.357 & 29.631 \\
Externally owned & 4114 & 0.152 & 0.359 & 3530 & 0.307 & 0.461 \\
Lack innovation finance & 4175 & 0.174 & 0.379 & 3530 & 0.478 & 0.500 \\
Face regulatory barriers & 4173 & 1.942 & 0.871 & 3530 & 0.206 & 0.404 \\
Government support & 4083 & 0.091 & 0.287 & & & \\
Govt support for innovation & & & & 3530 & 0.289 & 0.453 \\
Govt support for investment & & & & 3530 & 0.218 & 0.413 \\
Govt support for training etc. & & & & 3530 & 0.152 & 0.359 \\
Employment & 4177 & 213.384 & 715.714 & 3461 & 104.916 & 283.055 \\
Log capital intensity & 3970 & 10.837 & 0.865 & 2428 & 1.186 & 1.371 \\
Percentage with degree & 4177 & 16.176 & 14.626 & 3310 & 9.696 & 13.102 \\
Northern Ireland Location & & & & 3530 & 0.391 & 0.488 \\
\hline
\end{tabular}

Sources: Swiss Innovation Panel, waves 3-6; Irish Innovation Panel waves 2-5. 
Table 3: Knowledge Sourcing Models

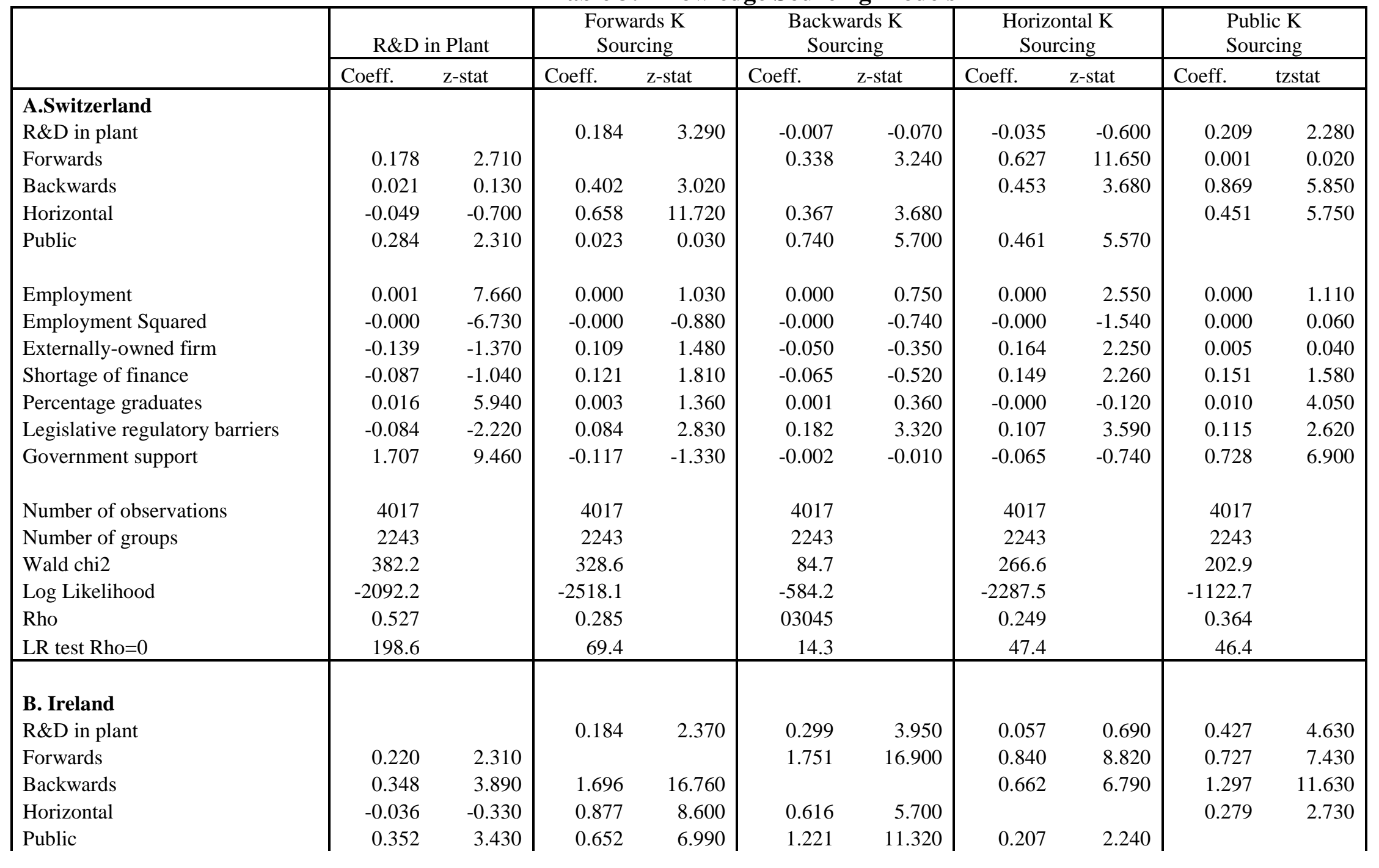


Notes and Sources: RE probit estimates. All models include constant terms and industry dummy variables at 2-digit level. Sources: Swiss Innovation Panel, waves 3-6; Irish Innovation Panel waves 2-5. 
Table 4: Innovation Production Functions

\begin{tabular}{|c|c|c|c|c|c|c|c|c|}
\hline \multirow[b]{2}{*}{ A. Switzerland } & \multicolumn{2}{|c|}{$\begin{array}{c}\text { Probability of } \\
\text { product innovation } \\
\text { RE probit }\end{array}$} & \multicolumn{2}{|c|}{$\begin{array}{c}\text { Probability of } \\
\text { process innovation } \\
\text { RE probit }\end{array}$} & \multicolumn{2}{|c|}{$\begin{array}{c}\text { \% innovative sales } \\
\text { (all firms) } \\
\text { RE tobit }\end{array}$} & \multicolumn{2}{|c|}{$\begin{array}{c}\text { \% innovative sales } \\
\text { (innovators only) } \\
\text { RE tobit }\end{array}$} \\
\hline & Coeff. & z-stat & Coeff. & z-stat & Coeff & z-stat & Coeff & z-stat \\
\hline R\&D in plant & 2.444 & 23.750 & 1.600 & 22.270 & 25.431 & 25.980 & 4.101 & 3.720 \\
\hline Forwards & 0.215 & 3.180 & 0.089 & 1.630 & 2.795 & 3.460 & 1.918 & 2.380 \\
\hline Backwards & -0.100 & -0.600 & 0.345 & 2.370 & -0.548 & -0.270 & -0.899 & -0.460 \\
\hline Horizontal & -0.134 & -1.830 & 0.035 & 0.590 & 0.200 & 0.230 & 1.131 & 1.330 \\
\hline Public & -0.162 & -1.310 & -0.140 & -1.540 & -0.542 & -0.420 & 0.573 & 0.450 \\
\hline Employment & 0.000 & 2.060 & 0.000 & 4.650 & 0.002 & 2.080 & 0.002 & 1.810 \\
\hline Employment Squared & -0.000 & -1.340 & -0.000 & -3.030 & -0.000 & -1.430 & -0.000 & -1.250 \\
\hline Plant vintage & 0.001 & 0.950 & -0.000 & -0.160 & -0.018 & -1.730 & -0.025 & -2.410 \\
\hline Externally-owned firm & 0.143 & 1.410 & -0.102 & -1.310 & 1.545 & 1.340 & 1.168 & 1.030 \\
\hline Shortage of finance & -0.216 & -2.520 & -0.065 & -0.930 & -0.065 & -0.060 & 0.994 & 0.930 \\
\hline Percentage graduates & 0.006 & 2.150 & -0.005 & -2.620 & 0.122 & 4.070 & 0.132 & 4.470 \\
\hline Legislative regulatory barriers & -0.042 & -1.090 & 0.077 & 2.420 & 0.351 & 0.750 & 1.194 & 2.540 \\
\hline Government support & 0.419 & 2.790 & 0.338 & 3.360 & 0.272 & 0.210 & -1.397 & -1.160 \\
\hline Number of observations & 3921 & & 3921 & & 3921 & & 2997 & \\
\hline Number of groups & 2213 & & 2213 & & 2213 & & 1811 & \\
\hline Left-censored & & & & & 1388 & & 464 & \\
\hline Wald chi2 & 621.2 & & 602.2 & & 1112.1 & & 290.0 & \\
\hline Log Likelihood & -1281.0 & & -2061.8 & & -12159.0 & & -11627.0 & \\
\hline Rho & 0.251 & & 0.250 & & 0.236 & & 0.251 & \\
\hline LR test Rho $=0$ & 20.9 & & 39.2 & & & & & \\
\hline B. Ireland & & & & & & & & \\
\hline $\mathrm{R} \& \mathrm{D}$ in plant & 1.206 & 13.600 & 0.489 & 7.630 & 16.066 & 10.900 & -2.538 & -1.730 \\
\hline Forwards & 0.487 & 4.390 & 0.148 & 1.730 & 7.144 & 3.870 & 3.716 & 2.280 \\
\hline
\end{tabular}




\begin{tabular}{|l|rr|rr|rr|rr|} 
Backwards & 0.477 & 4.660 & 0.469 & 5.780 & 7.472 & 4.200 & 2.646 & 1.670 \\
Publizontal & 0.288 & 2.160 & 0.216 & 2.110 & 3.326 & 1.620 & 0.058 & 0.030 \\
& -0.269 & -2.220 & 0.068 & 0.710 & -3.936 & -2.010 & -4.008 & -2.330 \\
Employment & & & & & & & & \\
Employment Squared & 0.001 & 3.000 & 0.001 & 4.450 & 0.012 & 2.380 & 0.000 & 0.000 \\
Plant vintage & -0.002 & -0.900 & -0.002 & -2.830 & -0.018 & -1.390 & 0.003 & 0.310 \\
Externally-owned firm & 0.001 & 0.570 & -0.001 & -1.400 & -0.093 & -3.760 & -0.111 & -5.140 \\
Shortage of finance & 0.290 & 3.190 & 0.215 & 3.000 & 3.870 & 2.330 & -1.046 & -0.640 \\
Percentage graduates & -0.076 & -1.100 & -0.138 & -2.440 & 1.036 & 0.790 & 3.944 & 2.470 \\
Government support: innovation & 0.008 & 2.390 & -0.007 & -2.770 & 0.202 & 3.610 & 2.810 & 2.280 \\
Government support: capital & 0.430 & 4.480 & 0.307 & 4.020 & 4.889 & 3.010 & 0.110 & 2.110 \\
Government support: training & -0.072 & -0.740 & 0.508 & 6.480 & 2.602 & 1.570 & -0.041 & -1.920 \\
Northern Ireland location & 0.403 & 3.510 & 0.005 & 0.050 & 4.235 & 2.310 & 6.762 & 4.130 \\
Legislative regulatory barriers & -0.075 & -0.940 & -0.169 & -2.710 & -1.710 & -1.120 & -0.168 & -0.110 \\
& -0.168 & -1.890 & 0.018 & 0.240 & -2.120 & -1.270 & 3.284 & 2.200 \\
Number of observations & & & & & & & & 1788 \\
Number of groups & 3215 & & 3215 & & 2954 & & 1323 & \\
Left-censored & 2036 & & 2032 & & 1955 & & & \\
Wald chi2 & & & & & & & & \\
Log Likelihood & 345.6 & & 364.0 & & 528.6 & & -764.9 & \\
Rho & -1515.4 & & -1791.7 & & -8812.3 & & & \\
LR test Rho=0 & & & & & & & & \\
\hline
\end{tabular}

Notes and Sources: RE tobit estimates. All models include constant terms and industry dummy variables at 2-digit level. Sources: Swiss Innovation Panel, waves 3-6; Irish Innovation Panel waves 2-5. 
Table 5: Productivity Equations Including Innovation Indicators

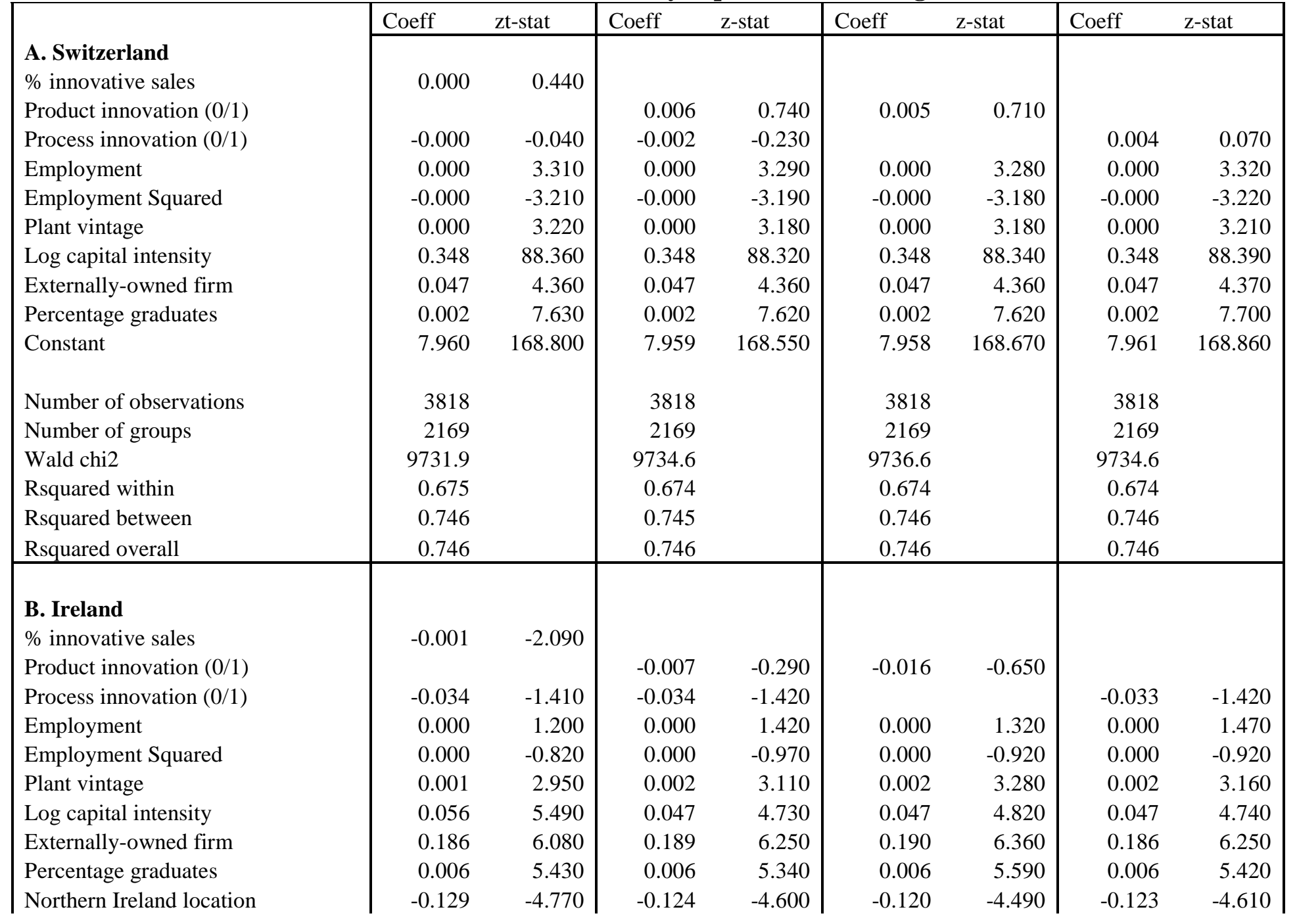




\begin{tabular}{|c|c|c|c|c|c|c|c|c|}
\hline Constant & 3.224 & 71.310 & 3.232 & 69.940 & 3.211 & 71.580 & 3.221 & 73.200 \\
\hline Number of observations & 1709 & & 1797 & & 1818 & & 1823 & \\
\hline Number of groups & 1268 & & 1318 & & 1333 & & 1332 & \\
\hline Wald chi2 & 417.2 & & 428.2 & & 434.8 & & 438.3 & \\
\hline Rsquared within & 0.172 & & 1.182 & & 0.181 & & 0.169 & \\
\hline Rsquared between & 0.202 & & 0.193 & & 0.194 & & 0.194 & \\
\hline Rsquared overall & 0.214 & & 0.208 & & 0.208 & & 0.207 & \\
\hline
\end{tabular}

Notes and Sources: RE GLS estimates. All models include constant terms and industry dummy variables at 2-digit level. Sources: Swiss Innovation Panel, waves 3-6; Irish Innovation Panel waves 2-5. 
Table 6: Productivity Equations Including Fitted Innovation Indicators

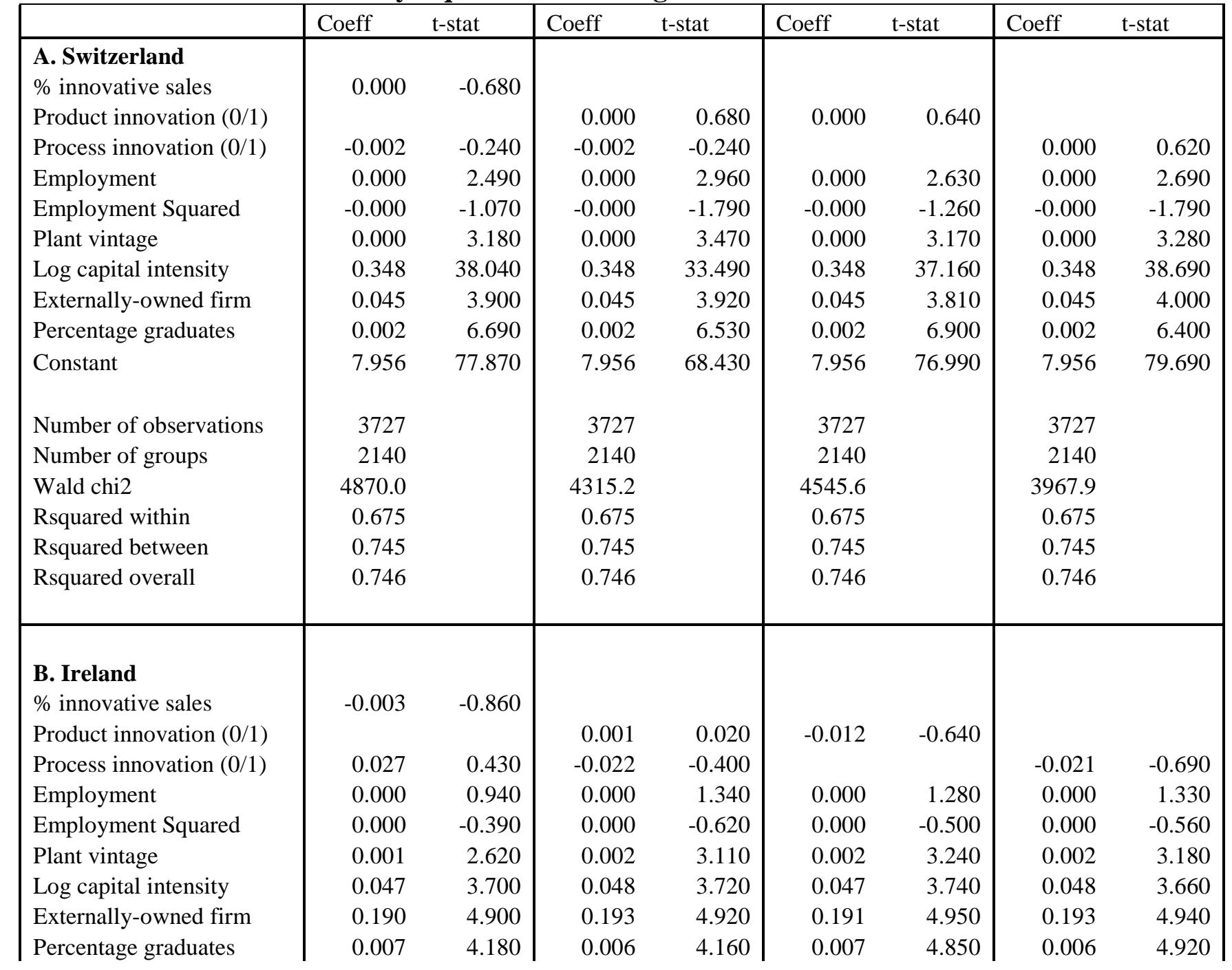




\begin{tabular}{|l|cc|rr|rr|rr|} 
Northern Ireland location & -0.123 & -5.580 & -0.125 & -5.290 & -0.123 & -5.310 & -0.124 & -5.430 \\
& 3.186 & 68.440 & 3.197 & 66.650 & 3.198 & 66.610 & 3.197 & 67.950 \\
Number of observations & 1850 & & & & & & & \\
Number of groups & 1351 & & 1850 & & 1850 & & 1850 & \\
Wald chi2 & 404.9 & & 426.5 & & 1351 & & 1351 & \\
Rsquared within & 0.186 & & 0.185 & & 482.4 & & 464.1 & \\
Rsquared between & 0.198 & & 0.197 & & 0.185 & & 0.185 & \\
Rsquared overall & 0.210 & & 0.210 & & 0.209 & & 0.197 & \\
\hline
\end{tabular}

Notes and Sources: RE GLS estimates. All models include constant terms and industry dummy variables at 2-digit level.

Sources: Swiss Innovation Panel, waves 3-6; Irish Innovation Panel waves 2-5. 
Figure 1: Time Series for Innovation Indicators

(a) Switzerland

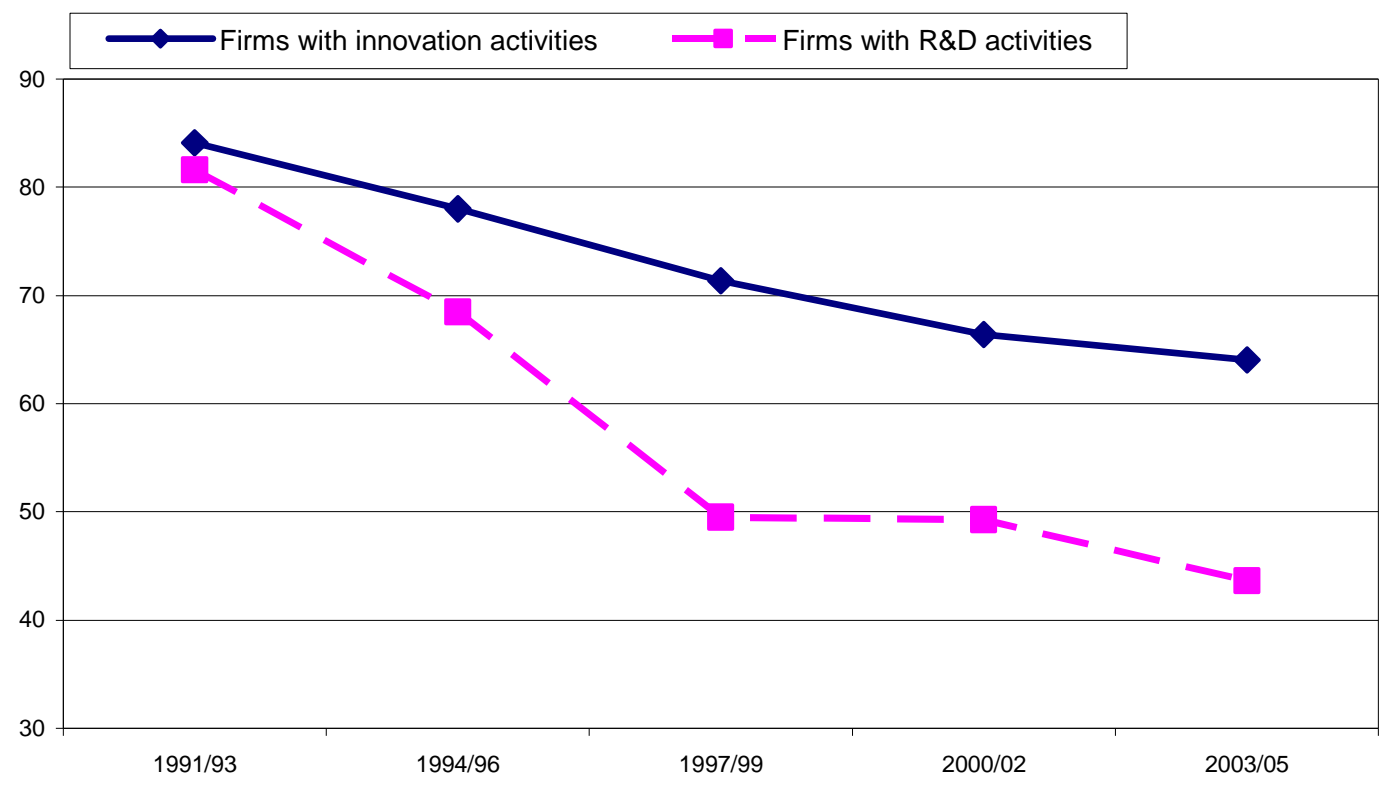

\section{(b) Ireland}

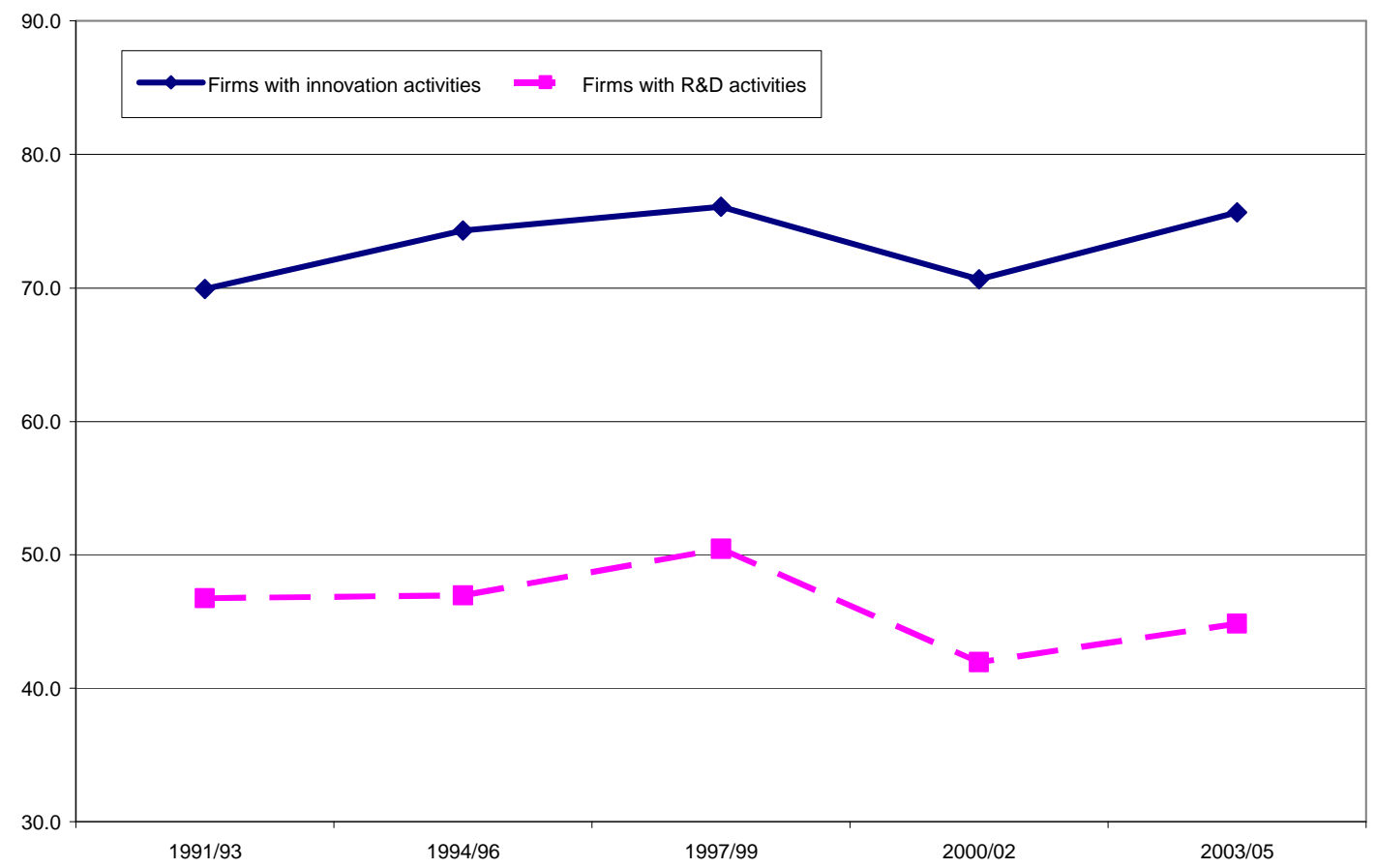

Notes: Firms with innovation activities reflects firms with either product or process innovation activities. Firms with R\&D are those firms with R\&D based in the firm. Sources: Swiss Innovation Survey; Irish Innovation Panel 
Table A1: Variable Definitions

Variables
Knowledge Sourcing
R\&D in plant
Forwards
Backwards
Horizontal
Public
Innovation
Product innovation $(0 / 1)$
Productivity
Value Added per employee
Process innovation $(0 / 1)$

Value Added per employee

\section{Other factors}

Plant vintage

Externally-owned

Shortage of finance

Legislative regulatory barriers

\section{Government support \\ Govt support: innovation}

Govt support: capital

Govt support: training

\section{Variable Definitions}

A binary indictor taking value one if the firm has an in-house R\&D capacity

A binary indictor taking value one if the firm has forwards links to customers as part of their innovation activity.

A binary indictor taking value one if the firm has backwards links to suppliers or external consultants as part of their innovation activity.

A binary indictor taking value one if the firm has links to competitors, or as part of joint venture activity, as part of their innovation activity.

A binary indictor taking value one if the firm has links to universities, public laboratories or other industry research centres as part of their innovation activity.

A binary variable taking value 1 if the firm introduced any new or improved product during the previous three years.

A binary variable taking value 1 if the firm introduced any new or improved product during the previous three years.

An indicator representing the percentage of firms' sales at the time of the survey accounted for by products which had been newly introduced or improved over the previous three years.

Value added is defined as sales less the cost of materials, expenditure on plant machinery and other fixed assets and expenditure on buildings. Both this measure and employment are taken in the year of the survey.

The age of the firm (in years) at the time of the survey.

A binary indicator taking value one if the firm was owned outside Ireland or Switzerland at the time of the survey.

A binary indicator taking value 1 if a firm reported that a lack of innovation finance was either a 'fairly important' or 'very important' barrier to innovation.

A binary indicator taking value 1 if a firm reported that regulatory barriers were either a 'fairly important' or 'very important' barrier to innovation.

A binary indicator taking value one if the firm had received government support for R\&D or innovation over the previous three years.

A binary indicator taking value one if the firm had received government support for its investment activities over the previous three years.

A binary indicator taking value one if the firm had received government support for its training activities over the previous 
Employment

Capital intensity

Percentage graduates

Northern Ireland location

three years.

Employment at the time of the survey.

Defined as expenditure on plant machinery and fixed assets and buildings per employee in the final year of each survey period Percentage of the workforce with a degree or equivalent qualification

A binary variable which takes value one if the firm is located in Northern Ireland

Sources: Swiss Innovation Panel, waves 3-6; Irish Innovation Panel waves 2-5. 
Table A2: Variable Correlations: Switzerland

\begin{tabular}{|c|c|c|c|c|c|c|c|c|c|}
\hline & $\begin{array}{l}\text { Product } \\
\text { Innov }\end{array}$ & $\begin{array}{l}\text { Process } \\
\text { Innov }\end{array}$ & $\begin{array}{l}\text { \% innov } \\
\text { Sales }\end{array}$ & $\begin{array}{l}\text { Log } \\
\text { value added }\end{array}$ & $\begin{array}{l}\text { R\&D } \\
\text { in house }\end{array}$ & $\begin{array}{l}\text { Forward } \\
\text { KS }\end{array}$ & $\begin{array}{l}\text { Backward } \\
\text { KS }\end{array}$ & $\begin{array}{l}\text { Horiz } \\
\text { KS }\end{array}$ & $\begin{array}{l}\text { Public } \\
\text { KS }\end{array}$ \\
\hline Product innov & 1.0000 & & & & & & & & \\
\hline Process innov & 0.4589 & 1.0000 & & & & & & & \\
\hline$\%$ innov sales & 0.4034 & 0.2951 & 1.0000 & & & & & & \\
\hline Log value added & 0.0714 & 0.0255 & 0.0094 & 1.0000 & & & & & \\
\hline R\&D in house & 0.7227 & 0.4931 & 0.3623 & 0.0923 & 1.0000 & & & & \\
\hline Forwards KS & 0.1330 & 0.0892 & 0.1117 & 0.0178 & 0.1238 & 1.0000 & & & \\
\hline Backwards KS & 0.0007 & 0.0475 & 0.0050 & -0.0099 & 0.0103 & 0.0664 & 1.0000 & & \\
\hline Horizontal KS & -0.0015 & 0.0303 & 0.0299 & 0.0157 & 0.0250 & 0.2069 & 0.0898 & 1.0000 & \\
\hline Public KS & 0.0760 & 0.0529 & 0.0706 & 0.0647 & 0.1160 & 0.0552 & 0.1278 & 0.1135 & 1.0000 \\
\hline Vintage & 0.0273 & 0.0398 & -0.0580 & 0.0321 & 0.0259 & -0.0205 & 0.0265 & 0.0201 & -0.0081 \\
\hline Foreign owned & 0.0807 & 0.0035 & 0.0613 & 0.1524 & 0.0756 & 0.0649 & -0.0161 & 0.0429 & 0.0419 \\
\hline Finance shortage & -0.0516 & -0.0050 & 0.0130 & -0.1495 & -0.0230 & 0.0499 & 0.0150 & 0.0509 & 0.0348 \\
\hline Regulatory issues & -0.0408 & 0.0353 & 0.0144 & -0.0200 & -0.0216 & 0.0592 & 0.0731 & 0.0791 & 0.0606 \\
\hline Govt support-innov & 0.1744 & 0.1564 & 0.1044 & 0.0213 & 0.2112 & 0.0297 & 0.0125 & 0.0172 & 0.1960 \\
\hline Employment & 0.1050 & 0.1121 & 0.0700 & 0.0716 & 0.1217 & 0.0317 & 0.0313 & 0.0648 & 0.1206 \\
\hline Capital intensity & 0.0613 & 0.0380 & 0.0208 & 0.8373 & 0.0840 & 0.0373 & -0.0051 & -0.0086 & 0.0350 \\
\hline Graduate workforce & 0.1752 & 0.0556 & 0.1824 & 0.2001 & 0.2036 & 0.0669 & 0.0064 & 0.0462 & 0.1671 \\
\hline
\end{tabular}

\begin{tabular}{|c|c|c|c|c|c|c|c|}
\hline & Vintage & $\begin{array}{l}\text { Foreign } \\
\text { Owned }\end{array}$ & $\begin{array}{l}\text { Lack } \\
\text { Cash }\end{array}$ & $\begin{array}{l}\text { Regulation } \\
\text { Barrier }\end{array}$ & $\begin{array}{l}\text { Govt } \\
\text { Support } \\
\text { Innov }\end{array}$ & $\begin{array}{l}\text { Govt } \\
\text { Support } \\
\text { Invest }\end{array}$ & $\begin{array}{l}\text { Govt } \\
\text { Support } \\
\text { Other }\end{array}$ \\
\hline Vintage & 1.0000 & & & & & & \\
\hline Foreign owned & -0.0877 & 1.0000 & & & & & \\
\hline Finance shortage & -0.0560 & -0.0767 & 1.0000 & & & & \\
\hline Regulatory issues & -0.0065 & -0.0618 & 0.1579 & 1.0000 & & & \\
\hline Govt support & 0.0092 & 0.0364 & 0.0510 & 0.0563 & 1.0000 & & \\
\hline Employment & 0.1516 & 0.0164 & -0.0655 & 0.0081 & 0.0785 & 1.0000 & \\
\hline Capital intensity & 0.0074 & 0.1077 & -0.1380 & 0.0036 & -0.0012 & 0.0340 & 1.0000 \\
\hline Graduate workforce & -0.0768 & 0.1549 & -0.0134 & -0.0403 & 0.1426 & 0.1584 & 0.0943 \\
\hline
\end{tabular}


Table A3: Variable Correlations: Ireland

\begin{tabular}{|c|c|c|c|c|c|c|c|c|c|}
\hline & $\begin{array}{l}\text { Product } \\
\text { Innov }\end{array}$ & $\begin{array}{l}\text { Process } \\
\text { Innov }\end{array}$ & $\begin{array}{l}\text { \% innov } \\
\text { Sales }\end{array}$ & $\begin{array}{l}\text { Log value } \\
\text { added }\end{array}$ & R\&D in house & $\begin{array}{l}\text { Forward } \\
\text { KS }\end{array}$ & $\begin{array}{l}\text { Backward } \\
\text { KS }\end{array}$ & $\begin{array}{l}\text { Horiz } \\
\text { KS }\end{array}$ & $\begin{array}{l}\text { Public } \\
\text { KS }\end{array}$ \\
\hline Product innov & 1.0000 & & & & & & & & \\
\hline Process innov & 0.2549 & 1.0000 & & & & & & & \\
\hline$\%$ innov sales & 0.5152 & 0.1601 & 1.0000 & & & & & & \\
\hline Log value added & 0.0698 & 0.0167 & -0.0195 & 1.0000 & & & & & \\
\hline R\&D in house & 0.4489 & 0.2601 & 0.2569 & 0.0203 & 1.0000 & & & & \\
\hline Forwards KS & 0.2347 & 0.2144 & 0.1868 & -0.0100 & 0.2168 & 1.0000 & & & \\
\hline Backwards KS & 0.2451 & 0.2646 & 0.1632 & 0.0277 & 0.2310 & 0.6107 & 1.0000 & & \\
\hline Horizontal KS & 0.1556 & 0.1388 & 0.0941 & 0.0087 & 0.1215 & 0.3681 & 0.3288 & 1.0000 & \\
\hline Public KS & 0.1834 & 0.2026 & 0.1136 & 0.0391 & 0.2394 & 0.4349 & 0.4932 & 0.2514 & 1.0000 \\
\hline Vintage & -0.0133 & -0.0307 & -0.1051 & 0.1015 & -0.0524 & -0.0289 & 0.0026 & 0.0178 & 0.0174 \\
\hline Foreign owned & 0.1337 & 0.1388 & 0.0963 & 0.1588 & 0.0182 & 0.0983 & 0.1406 & -0.0013 & 0.1445 \\
\hline Finance shortage & -0.0624 & -0.0799 & -0.0052 & -0.0394 & -0.0658 & -0.0376 & -0.0554 & -0.0129 & -0.0401 \\
\hline Regulatory issues & -0.0071 & 0.0010 & -0.0158 & -0.0070 & 0.0490 & 0.0005 & 0.0043 & 0.0243 & 0.0270 \\
\hline Govt support-innov & 0.2962 & 0.2200 & 0.2148 & 0.0287 & 0.4027 & 0.2499 & 0.2499 & 0.1508 & 0.3214 \\
\hline Govt support-invest & 0.1255 & 0.2241 & 0.0809 & -0.0918 & 0.1674 & 0.1440 & 0.1334 & 0.1060 & 0.1658 \\
\hline Govt support-other & 0.1527 & 0.0801 & 0.1033 & -0.0465 & 0.2000 & 0.1075 & 0.0812 & 0.0977 & 0.1023 \\
\hline Employment & 0.1203 & 0.1315 & 0.0881 & 0.0602 & 0.1066 & 0.1065 & 0.1694 & 0.0999 & 0.2060 \\
\hline Capital intensity & 0.1099 & 0.2422 & 0.0804 & 0.1793 & 0.1382 & 0.0680 & 0.1118 & 0.0479 & 0.1215 \\
\hline Graduate workforce & 0.1115 & -0.0125 & 0.1002 & 0.1914 & 0.1184 & 0.1027 & 0.0780 & 0.0564 & 0.1321 \\
\hline Employment & -0.0764 & -0.0787 & -0.0583 & -0.1001 & -0.0786 & -0.0171 & -0.0325 & -0.0517 & -0.0139 \\
\hline
\end{tabular}




\begin{tabular}{|c|c|c|c|c|c|c|c|c|c|c|}
\hline & Vintage & $\begin{array}{l}\text { Foreign } \\
\text { Owned }\end{array}$ & $\begin{array}{l}\text { Lack } \\
\text { Cash }\end{array}$ & $\begin{array}{l}\text { Regulation } \\
\text { Barrier }\end{array}$ & $\begin{array}{l}\text { Govt } \\
\text { Support } \\
\text { Innov }\end{array}$ & $\begin{array}{l}\text { Govt } \\
\text { Support } \\
\text { Invest }\end{array}$ & $\begin{array}{l}\text { Govt } \\
\text { Support } \\
\text { Other }\end{array}$ & Employ & $\begin{array}{l}\text { Cap } \\
\text { Intensity }\end{array}$ & $\begin{array}{l}\text { Graduate } \\
\text { Wforce }\end{array}$ \\
\hline Vintage & 1.0000 & & & & & & & & & \\
\hline Foreign owned & 0.0431 & 1.0000 & & & & & & & & \\
\hline Finance shortage & -0.0238 & -0.0766 & 1.0000 & & & & & & & \\
\hline Regulatory issues & -0.0034 & -0.0861 & 0.1229 & 1.0000 & & & & & & \\
\hline Govt support-innov & -0.0715 & 0.0325 & -0.0309 & -0.0416 & 1.0000 & & & & & \\
\hline Govt support-invest & -0.0290 & 0.0860 & -0.0448 & -0.0487 & 0.3267 & 1.0000 & & & & \\
\hline Govt support-other & -0.0415 & -0.0592 & -0.0196 & -0.0857 & 0.3223 & 0.2465 & 1.0000 & & & \\
\hline Employment & 0.1081 & 0.2838 & -0.0388 & -0.0322 & 0.1220 & 0.1450 & 0.0121 & 1.0000 & & \\
\hline Capital intensity & -0.0374 & 0.1515 & -0.0509 & -0.0003 & 0.1267 & 0.1380 & 0.0045 & 0.0643 & 1.0000 & \\
\hline Graduate workforce & -0.0069 & 0.1894 & 0.0246 & 0.0432 & 0.1227 & -0.0204 & 0.0184 & 0.0946 & 0.1247 & 1.0000 \\
\hline Employment & 0.0666 & -0.1073 & 0.0470 & 0.0084 & -0.0132 & 0.0903 & 0.0827 & -0.0052 & -0.0619 & -0.0855 \\
\hline
\end{tabular}




\section{References}

Arvanitis, S. (2008): Innovation and Labour Productivity in the Swiss Manufacturing Sector: An Analysis based on Firm panel Data, in C. van Beers, A. Kleinknecht, R. Ortt and R. Verburg (eds.), Determinants of Innovative Behaviour: A Firm's Internal Practices and Its External Environment, Palgrave, London.

Arvanitis, S., von Arx, J., Hollenstein, H. and N. Sydow (2004): Innovationsaktivitäten in der Schweizer Wirtschaft - Eine Analyse der Ergebnisse der Innovationserhebung 2002, Strukturberichterstattung Nr. 24, hrsg. vom Staatssekretariat für Wirtschaft, Bern.

Arvanitis, S., Bezzola, M, Donzé, L., Hollenstein, H. and D. Marmet (2001): Innovationsaktivitäten in der Schweizer Wirtschaft. Eine Analyse der Ergebnisse der Innovationserhebung 1999, Studienreihe Strukturberichterstattung Nr. 5, hrsg. vom Staatssekretariat für Wirtschaft, Bern.

Arvanitis, S., Donzè, L., Hollenstein, H. und S. Lenz (1998): Innovationsaktivitäten in der Schweizer Wirtschaft, Teil I: Industrie, Studienreihe Strukturberichterstattung, hrsg. vom Bundesamt für Wirtschaft und Arbeit, Bern.

Arvanitis, S., Hollenstein, H., Sydow, N. and M. Wörter (2007): Innovationsaktivitäten in der Schweizer Wirtschaft - Eine Analyse der Ergebnisse der Innovationserhebung 2005, Strukturberichterstattung Nr. 34, hrsg. vom Staatssekretariat für Wirtschaft, Bern.

Atkeson, and Kehoe. 2005. Modelling and Measuring Organization Capital. Journal of Political Economy 113:1026-1053.

Beugelsdijck, P J, and M Cornet. 2001. How far do they reach? The localisation of industrial and academic spillovers in the Netherlands. Centre discussion paper (2001):47.

Buiseret, T, H M Cameron, and L Georgiou. 1995. What differences does it make? Additionality in the public support of $\mathrm{R} \& \mathrm{D}$ in large firms. International Journal Of Technology Management 10 (4-6):587-600.

Cassiman, B, and R Veugelers. 2002. R\&D cooperation and spillovers: some empirial evidence from Belgium The American Economic Review 92 (4):1169-1184.

Caves, R E. 1998. Industrial Organization and New Findings and the Turnover and Mobility of Firms. Journal Of Economic Literature 36 (4):1947-82.

Cohen, W M, and D A Levinthal. 1989. Innovation and Learning: the two faces of R\&D. The Economic Journal 99:569-596.

1990. Absorptive capacity: a new perspective on learning and innovation. Administrative Science Quarterly 35:128-152.

Crepon, AD , A Hughes, P Lee, and J Mairesse. 1998. Research, Innovation and Productivity: An econometric analysis at the firm level. Economics of Innovation and New Technology 7:115-158.

Del Barrio-Castro, T., and J. Garcia-Quevedo. 2005. Effects of university research on the geography of innovation. Regional Studies 39 (9):1217-1229.

Driffield, N L., Love J H. 2005. Who gains fom whom? Spillovers, competition and technology sourching in the foreign-owned sector of UK manufacturing. Scottish Journal of Political Economy 52:663-686. 
Edquist, C. 2004. Systems of Innovation - A Critical Review of The State of the Art. Edited by J. Fagerberg, D. Mowery and R. Nelson, Handbook of Innovation: Oxford University Press.

Edquist, C, and L Hommen. 2008. Small Country Innovation Systems - Globalization, Change and Policy in Asia and Europe. Cheltenham Edward Elgar.

Falk, R. 2004. Behavioural Additionality effects of R\&D Subsidies: Austrian Institute of Economic Research.

Geroski, P A. 1990. Innovation, Technological Opportunities and Market Structure. Oxford Econonomic Papers 42:586-602.

Geroski, P, S Machin, and J Van Reenen. 1993. The Profitability of Innovating Firms. Rand Journal of Economics 24 (2):198-211.

Griliches, Z. 1992. The Search for Research-And-Development Spillovers. Scandinavian Journal of Economics 94:S29-S47.

1995. R\&D and Productivity: Econometric Results and Measurement Issues. Edited by P. Stoneman, Handbook of the Economics of Innovation and Technological Change. Oxford: Blackwell.

Guellec, D, and B van Pottelsberghe. 2004. From R\&D to productivity growth: do the institutional settings and the source of funds matter? Oxford Bulletin of Economics and Statistics 66:353-378.

Hansen, M T, and J Birkinshaw. 2007. What is the Weakest Link in your Innovation Value Chain? Harvard Business Review Forthcoming.

Hemphill, T A. 2003. Cooperative strategy, Technology Innovation and Product Development in Industrial Companies. International Journal of Production Economics 69 (2):169-176.

Hewitt-Dundas, N, B Anderson-Callaghan, M Crone, J Murray, and S Roper. 2002. Learning from the Best - Knowledge Transfers from Mulitinational Plants in Ireland - A North-South Comparison. Belfast: NIERC/EAC.

Horn, Paul M. 2005. The Changing Nature of Innovation. Research Technology Management 48 (6):28-33.

Irwin, D A., Klenow, P J. 1996. High-Tech R\&D Subsidies - Estimating the Effects of Sematech. Journal of International Economics 40:323-344.

Jordan, D , and E O'Leary. 2007. Sources of innovation in Irish SMEs: Evidence from two Irish regions. Paper read at British-Irish Regional Science Association Annual Conference, at Bangor.

Joshi, A W, and S Sharma. 2004. Customer Knowledge Development: Antecedents and Impact on New Product Performance. Journal of Marketing 68 (4):47-59.

Karkkainen, H, P Phiippo, and M Tuominen. 2001. Ten Tools for Customer-Driven Product Development in Industrial Companies. The International Journal of Production Economics 69 (2):161-176.

Klette, T. J, and F Johansen. 1998. Accumulation of R\&D Capital and Dynamic Firm Performance: a not-so-Fixed Effect Model. Annales de Economie et de Statistique 49-50:389-419. 
Klette, T. J, J Moen, and Z Griliches. 2000. Do subsidies to commercial R\&D reduce market failures? Microeconometric evaluation studies. Research Policy 29 (45):471-495.

KOF-Analysen (2007): Prognose 2008/2009 - Schweizer Wirtschaft in der Rezession, ETH Zurich, KOF, Zurich.

Link, A N, D Paton, and D S Siegel. 2005. An Econometric Analysis of Trends in Research Joint Venture Activity. Managerial and Decision Economics 26 (2):149-158.

Loof, H, and A Heshmati. 2001. On the Relationship between Innovation and Performance: A Sensitivity Analysis. Stockholm School of Economics.

- 2002. Knowledge capital and performance heterogeneity: A firm level innovation study. International Journal of Production Economics 76:61-85.

Love, J H , and M A Mansury. 2007. External Linkages, R\&D and Innovation Performance in US Business Services. Industry and Innovation forthcoming.

Love, J H, and S Roper. 1999. The determinants of innovation: R\&D, technology transfer and networking effects. Review of Industrial Organisation 15 (1):4364 .

1999. R\&D Technology Transfer and Networking Effetcs on Innovation Intensity. Review of Industrial Organisation 15:43-64.

2001. Networking and Innovation Success: A Comparison of UK, German and Irish Companies. Research Policy 30:643-661.

Love, J H, and Roper S. 2004. The Organisation of Innovation: Collaboration, Cooperation and Multifunctional Groups in UK and German Manufacturing. Cambridge Journal Of Economics 28:379-395.

Luukkonen, T. 2000. Additionality of EU Framework Programmes. Research Policy 29:711-724.

Maddala, G. 1983. Limited Dependent and Qualitative Variables in Econometrics. New York: Cambridge University Press.

Meehan, E. 2000. Britain's Irish Question: Britain's European Question?: British-Irish relations in the context of the European Union and the Belfast Agreement. Review of International Studies 26 (1):83-97.

Nelson, R R. 1993. National Systems of Innovation: A comparative Study. Oxford: Oxford University Press.

Nelson, R R, and S Winter. 1982. An Evolutionary Theory of Economic Change. Cambridge, Massachusetts: Harvard University Press.

O'Malley, E, S Roper, and N Hewitt-Dundas. 2008. High growth and innovation with low R\&D: The case of Ireland. In Small Economy Innovation System; Comparing Globalization, Change and Policy in Asia and Europe, edited by C. Edquist and L. Hommen: Elgar.

OECD. 2006. Government R\&D Funding and Company Bhaviour: Measuring Behavioural Additionality. Paris. 
Perkmann, M, and K Walsh. 2007. 'Relationship-based university-industry links and open innovation: towards a research agenda' (with $\mathrm{K}$ Walsh). , forthcoming International Journal of Management Reviews Forthcoming.

Pittaway, L, M Robertson, K Munir, D Denyer, and A Neely. 2004. Networking and Innovation: A Systematic Review of the Evidence. International Journal of Management Reviews 5/6 (3/4):137-168.

Roper, S , J Youtie, P Shapira, and A Fernandez-Ribas. 2008. Knowledge, Capabilities and Manufacturing Innovation: A US-Europe Comparison'. Regional Studies Forthcoming.

Roper, S, and N Hewitt-Dundas. 1998. Innovation, Networks and the Diffusion of Manufacturing Best Practice: A Comparison of Northern Ireland and the Republic of Ireland. Belfast: NIERC.

- 2001. Grant assistance and small firm development in Northern Ireland and the Republic of Ireland. Scottish Journal of Political Economy 48 (1):99-117.

Roper, S, and J H Love. 2005. Innovation Success and Business Performance - An All-Island Analysis. In All Island Business Model Research Report: InterTradeIreland.

Roper, S, J H Love, and J Du. 2008. Modelling the Innovation Value Chain. Research Policy 37 (6-7):961-977.

Roper, S. Ashcroft, B., Love, J H., Dunlop, S., Hofmann, H. Vogler-Ludwig, K. 1996. Product Innovation and Development in UK, German and Irish Manufacturing: Queen's University of Belfast/University of Strathclyde/info Institut.

Roper, S. Du, J., Love J H. 2006 Knowledge sourcing and Innovation: Aston Business School, Birmingham.

Santoro, M. D., and P. E. Bierly. 2006. Facilitators of knowledge transfer in university-industry collaborations: A knowledge-based perspective. Ieee Transactions on Engineering Management 53 (4):495-507.

Schmidt, T. 2005. Absorptive Capacity - One Size Fits All? A Firm-Level Analysis of Absorptive Capacity for Different Kinds of Knowledge. In ZEW Discussion Paper

Shelanski, H A, and P G Klein. 1995. Empirical research in transaction cost economics: a review and assessment. Journal of Law, Economics and Organisation 11 (2):335-361.

Smith, D J, and D Tranfield. 2005. Talented suppliers? Strategic change and innovation in the UK aerospace industry. $R \& D$ Management 35 (1):37-49.

Trajtenberg, M. 2001. Innovation in Israel 1968-1997: a comparative analysis using patent data. Research Policy 30 (3):363-389.

Veugelers, R, and B Cassiman. 1999. Make and Buy in Innovation Strategies: Evidence from Belgian manufacturing firms. Research Policy 28 (1):63-80.

Woerter, M. (2008): Driving Forces for Research and Development Strategies, Ms., Zurich (an earlier version is available as KOF Working Paper No. 184, December 2007). 
Wrynn, J. 1997. Foreign Direct Investment to a Peripheral Country - The Case of Ireland. Edited by B. Fynes and S. Ennis, Competing from the Periphery. Dublin: Oaktree Press.

Zahra, S A, and G George. 2002. Absorptive capacity: a review, re-conceptualization, and extension. Academy of management review 27:185-203. 